\title{
Genetic variability of Anthoxanthum aristatum Boiss. (Poaceae) at the non-native range limit
}

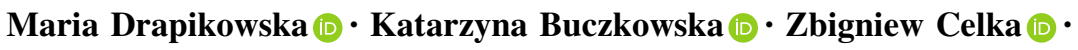 \\ Piotr Szkudlarz $\mathbb{D} \cdot$ Bogdan Jackowiak $(\mathbb{D}$
}

Received: 24 May 2019/Accepted: 21 October 2019/Published online: 1 November 2019

(C) The Author(s) 2019

\begin{abstract}
Anthoxanthum aristatum Boiss. is native to southern and western Europe and North Africa. In Central Europe this species is recognized as invasive. Its ability to colonize various habitats may result from a high level of polymorphic isozyme loci and high morphological variability. The aim of this study was to recognize the degree of genetic diversity of the studied invasive species at its non-native range limit using molecular markers. The examined plant material consisted of 70 samples collected from 7 populations originating from various habitats: arable fields, recently abandoned field and sandy grassland. Ninety-six the Directed Amplification of Minisatellite-region DNA loci and 82 Sequence-Related Amplified Polymorphism loci were detected. The genetic diversity at the species level was high. The majority of genetic variation was present within populations $(68 \%$ and $66 \%$ ), while the remaining molecular variation
\end{abstract}

M. Drapikowska

Department of Ecology and Environmental Protection, Faculty of Environmental Engineering and Spatial Management, Poznań University of Life Sciences, Poznań, Poland

K. Buczkowska Department of Genetics, Faculty of Biology, Adam Mickiewicz University in Poznań, Poznań, Poland

Z. Celka · P. Szkudlarz · B. Jackowiak ( $₫)$ Department of Plant Taxonomy, Faculty of Biology, Adam Mickiewicz University in Poznań, Poznań, Poland e-mail: bogjack@amu.edu.pl was distributed among populations within and among habitat types. Specimens originating from sandy grassland populations were grouped together in one cluster that was genetically distinct from the arable field and fallow populations. The high genetic diversity populations at the A. aristatum non-native range limit in Central Europe and their marked diversity in arable field and sandy grassland habitats suggest that this species may systematically cross both geographical and ecological barriers.

Keywords Alien species - Central Europe $\cdot$ Crop weeds · DAMD markers - Genetic diversity - SRAP markers

\section{Introduction}

Knowledge of the variation and genetic structure of weed populations occurring at the borders of the nonnative ranges of species may be crucial to understanding the biology of these species and planning measures to prevent their invasion. Interesting subjects for this type of research are the populations of Anthoxanthum aristatum Boiss. located at the species eastern nonnative range limit. A. aristatum is an annual with loose tufts, flowering from May to June and sometimes again in summer and autumn. This species is distributed naturally in West Europe and North Africa in 
the Mediterranean and Atlantic regions (Kästner et al. 2001). After accidental introductions to Germany during the Napoleonic period (Hegi 1909), by the late nineteenth century, it had spread into the Netherlands and all over Germany. In subsequent decades, $A$. aristatum spread throughout western and central Poland and migrated towards the country's eastern border, which it finally reached in the 1990s (Ciosek and Skrzyczyńska 1997). Beyond Europe, A. aristatum has spread to North America, Australia, New Zealand (Howell and Sawyer 2006; Randall 2007), and Asia (e.g., Mito and Uesugi 2004).

Within its natural range, A. aristatum occupies habitats of differing fertility composed of mesophilic deciduous forests (Rivas-Martínez et al. 1986), fertile grasslands (Fernández-Moya et al. 2010), mountain swards and pastures (Santa-Bárbara et al. 2003), communities connected to the edges of periodic ponds (Brullo et al. 2007; Fraga i Arguimbau 2008), grapevine fields and ruderal habitats (pers. observ.). Within its non-native range, A. aristatum mainly occupies oligotrophic crop fields, sandy grasslands, roadsides, fallow lands and wastelands (Schneider et al. 1994; Ryves et al. 1996; Niemann and Zwerger 2006; Pinke et al. 2006).

In Poland, annual vernal-grass is recognized as an invasive species (Tokarska-Guzik 2005). It has the highest number of localities in western and central Poland (Zając and Zając 2001). The spread of $A$. aristatum in Poland and its invasion into new habitats pose an increasing threat to the country's crops. The number of its localities is rising, which indicates that the species should be monitored. Particularly alarming is its spread to new, more fertile habitats (Skrajna and Skrzyczyńska 2007). In addition, this species can be found in sandy grasslands and along roadsides (Jackowiak et al. 1990). Less frequently, it grows in open pine, birch or pine-oak forests of post-agricultural lands, at the forest-field borders and on sandy forest roads and roadsides (Woziwoda 2010; Bomanowska et al. 2014).

A. aristatum shows considerable morphological variability and genetic differentiation in both its native and non-native ranges (Pimentel et al. 2010; Drapikowska 2013; Drapikowska et al. 2013). Its ability to colonize various non-native habitats in Poland may result from a high level of polymorphic isozyme loci and high morphological variability previously observed in A. aristatum populations from Central and western Poland (Drapikowska et al. 2012; Drapikowska 2013).

In this study, we used molecular markers to better understand the variability and genetic structure of $A$. aristatum populations in different habitats at the nonnative range limit of the species. Molecular biology offers many types of genetic markers that can be used in population genetic studies. PCR-based Single Primer Amplification Reaction (SPAR) markers, e.g., Random Amplification of Polymorphic DNA (RAPD), Inter Simple Sequence Repeats (ISSR) and Intron-Splice Junction (ISJ), are useful because they enable simultaneous detection of multiple polymorphic loci across the entire genome and do not require knowledge of the genome to design primers. These markers have been applied to the analysis of genetic variation in many groups of plants, including grasses (Vanderpoorten and Engels 2003; Alwala et al. 2008; Buczkowska et al. 2010). This group of markers also includes the Directed Amplification of Minisatelliteregion DNA (DAMD), introduced by Heath et al. (1993) and, more recently, Sequence-Related Amplified Polymorphism (SRAP) developed by $\mathrm{Li}$ and Quiros (2001), which target the coding regions of the genome. These markers should be employed for research addressing new hypotheses in plant systematics, biogeography, conservation and ecology (Robarts and Wolfe 2014).

The aim of this study was: (1) to determine the degree of genetic diversity of $A$. aristatum at the species level at the limit of its non-native range, (2) to investigate significant genetic differences among populations representing arable field and sandy grassland habitats.

\section{Materials and methods}

The studied populations of $A$. aristatum are located in western Poland, near the eastern limit of its non-native range in Central Europe (Fig. 1). The plant material used in this study consisted of 70 samples collected from 7 populations (10 samples per populations) originating from two type of habitats: periodically disturbed habitats (sandy grassland near field roadside-FR, sandy grassland adjacent arable field-GA and sandy grassland on the edge of a pine forest-GF) and regularly disturbed habitats (arable fields-AF, recently abandoned field-RF) (Table 1). From each 
Fig. 1 Distribution of Anthoxanthum aristatum in Europe based on the authors' investigations and numerous literature sources (incl. Valdés et al. 2009). 1 -native range, 2 primary localities beyond the native range, 3 -nonnative range, 4 - secondary localities beyond the nonnative range, 5-research localities

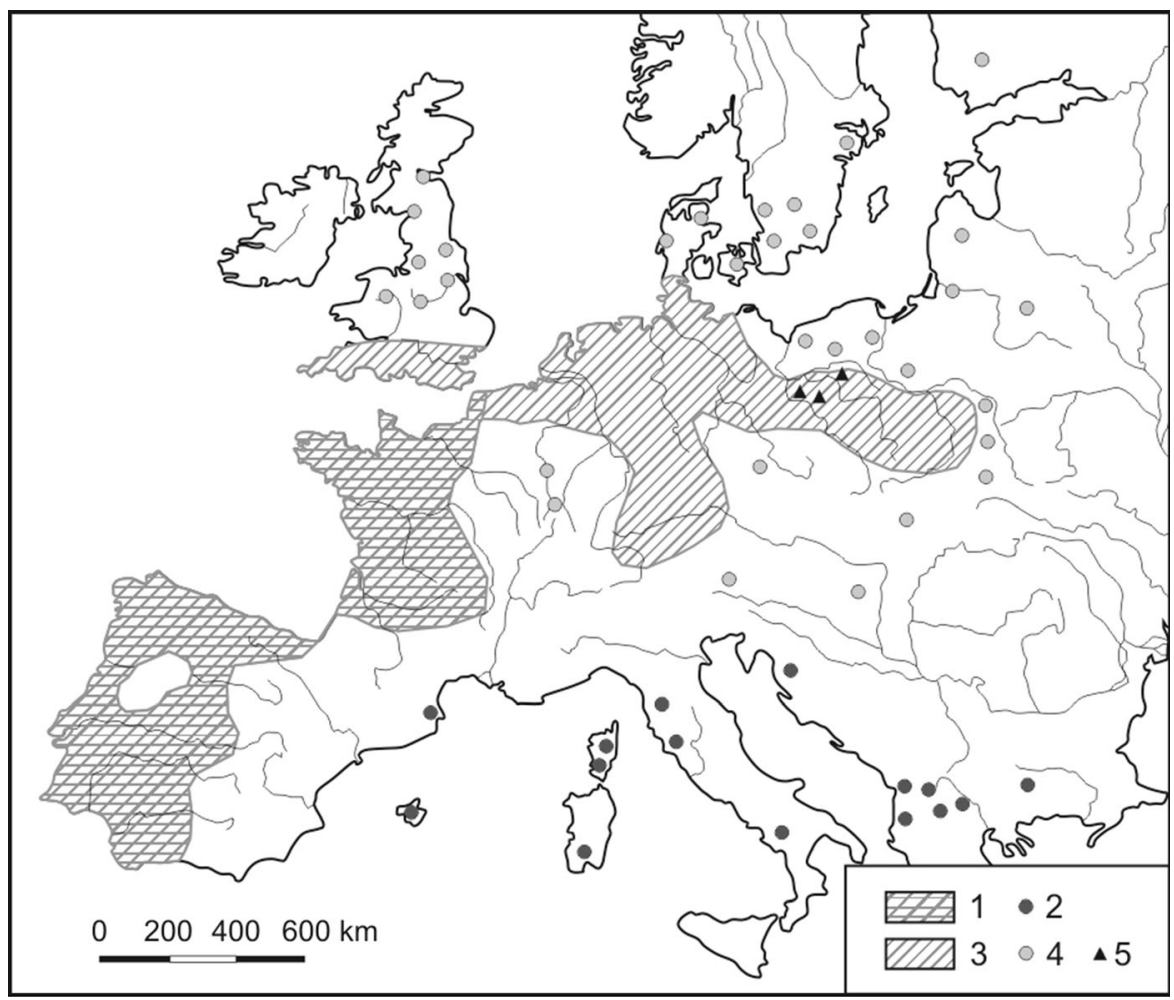

Table 1 Anthoxanthum aristatum sample collection sites in Western Poland

\begin{tabular}{|c|c|c|c|}
\hline $\begin{array}{l}\text { No. of } \\
\text { population }\end{array}$ & Geographic region & Habitat type & Geographic coordinates \\
\hline \multicolumn{4}{|c|}{ Populations occurring in the periodically disturbed habitats (PDH) } \\
\hline P1 & Chlebowo, Noteć Forest & Sandy grassland near arable field-GA & $\begin{array}{l}\mathrm{N} 52^{\circ} 44^{\prime} 51.0^{\prime \prime} \\
\mathrm{E} 16^{\circ} 45^{\prime} 58.5^{\prime \prime}\end{array}$ \\
\hline $\mathrm{P} 2$ & Chlebowo, Noteć Forest & Sandy grassland adjacent field roadside-FR & $\begin{array}{l}\mathrm{N} 52^{\circ} 44^{\prime} 49.2^{\prime \prime} \\
\mathrm{E} 16^{\circ} 45^{\prime} 48.5^{\prime \prime}\end{array}$ \\
\hline P3 & Chlebowo, Noteć Forest & $\begin{array}{l}\text { Sandy grassland on the edge of pine forest- } \\
\text { GF }\end{array}$ & $\begin{array}{l}\mathrm{N} 52^{\circ} 44^{\prime} 50.1^{\prime \prime} \\
\mathrm{E} 16^{\circ} 46^{\prime} 02.2^{\prime \prime}\end{array}$ \\
\hline \multicolumn{4}{|c|}{ Populations occurring in the regularly disturbed habitats (RDH) } \\
\hline P4 & Gęstowice, Rzepin Forest & Recently abandoned field-RF & $\begin{array}{l}\mathrm{N} 52^{\circ} 09^{\prime} 32.3^{\prime \prime} \\
\mathrm{E} 14^{\circ} 53^{\prime} 20.7^{\prime \prime}\end{array}$ \\
\hline P5 & Chlebowo, Noteć Forest & Arable field-AF & $\begin{array}{l}\mathrm{N} 52^{\circ} 44^{\prime} 51.4^{\prime \prime} \\
\mathrm{E} 16^{\circ} 45^{\prime} 59.8^{\prime \prime}\end{array}$ \\
\hline P6 & Wrzeszczyna, Noteć Forest & Arable field-AF & $\begin{array}{l}\mathrm{N} 52^{\circ} 52^{\prime} 16.9^{\prime \prime} \\
\mathrm{E} 16^{\circ} 14^{\prime} 48.2^{\prime \prime}\end{array}$ \\
\hline P7 & $\begin{array}{l}\text { Nowa Tuchorza, Nowy Tomyśl } \\
\text { Sandur }\end{array}$ & Arable field-AF & $\begin{array}{l}\mathrm{N} 52^{\circ} 12^{\prime} 24.2^{\prime \prime} \\
\mathrm{E} 16^{\circ} 04^{\prime} 38.3^{\prime \prime}\end{array}$ \\
\hline
\end{tabular}


collected plant, all leaves were placed in silica gel or in a plastic bag and frozen upon arrival at the laboratory.

Localities in which plant material was collected for genetic analyses were investigated in floristic and habitat (ecological) terms. In each locality, a phytosociological relevé was made using the Braun-Blanquet method (Oberdorfer et al. 2001). Next, based on the Ellenberg method (Ellenberg et al. 1992), the mean ecological indicator values for each studied area and two distinguished groups of habitats: arable field and sandy grassland, were calculated.

Total genomic DNA was extracted from approximately $1 \mathrm{~cm}^{2}$ of frozen or silica gel dried plants. In the case of frozen samples, the leaves were ground with steel beads in a Bioprep-24 Homogenizer (BioEquip) for $35 \mathrm{~s}$, and the standard CTAB procedure (Murray and Thompson 1980), downscaled to fit $1.5 \mathrm{ml}$ Eppendorf tubes, was used for DNA extraction. For the extraction of DNA from silica gel material, the Novabeads Plant DNA Kit (Novazym) was used. Isolated DNA was dissolved in TE buffer and stored at $-20{ }^{\circ} \mathrm{C}$. The quality of isolated DNA was evaluated by electrophoresis in $0.8 \%$ agarose gels, and the concentration and purity of DNA samples were determined using the Epoch $^{\mathrm{TM}}$ Multi-Volume Spectrophotometer System (BioTek).

A set of 23 DAMD primers (Karaca et al. 2008; Karaca and Ince 2008; Sharma et al. 2011) was screened, which enabled us to choose six primers that amplified and produced reproducible and clear banding patterns for further analysis (Table 2). A preliminary screen was carried out using an annealing temperature gradient to optimize the PCR conditions. PCR was performed in $25 \mu \mathrm{l}$ reaction volumes containing $40 \mathrm{ng}$ of genomic DNA, $0.5 \mu \mathrm{M}$ primer (Sigma), $0.5 \mathrm{mg} / \mathrm{ml}$ of BSA (Sigma), $1.5 \mathrm{mM} \mathrm{MgCl}_{2}$, $200 \mu \mathrm{M}$ of each dNTP (Novazym), $1 \times$ PCR buffer $\left(20 \mathrm{mM}\left(\mathrm{NH}_{4}\right) \mathrm{SO}_{4}, 50 \mathrm{mM}\right.$ Tris- $\mathrm{HCl}, \mathrm{pH} 9.0$ at $25^{\circ} \mathrm{C}$ ), and $1 \mathrm{U}$ of Taq Allegro polymerase (Novazym). The amplifications were carried out in a BIOGENER Thermocycler with a heated lid under the following amplification conditions: $94{ }^{\circ} \mathrm{C}$ for $4 \mathrm{~min}$ followed by 45 cycles at $94{ }^{\circ} \mathrm{C}$ for $60 \mathrm{~s}, 56{ }^{\circ} \mathrm{C}$ for $90 \mathrm{~s}$, and $72{ }^{\circ} \mathrm{C}$ for $2 \mathrm{~min}$, and a final elongation at $72{ }^{\circ} \mathrm{C}$ for $7 \mathrm{~min}$.

The protocol for SRAP analysis was based on $\mathrm{Li}$ and Quiros (2001). Initially, a total of 27 different SRAP primers were tested according to $\mathrm{Li}$ and Quiros (2001), Nie et al. (2014) and Zitouna et al. (2015). Finally, eight primer pairs that produced clear bands were chosen for further analysis (Table 3). These pairs were selected from the 27 combinations of 11 forward (Me1-Me11) and 12 reverse (Em1-5, 7-9, 11, 12, $14,15)$ primers. PCR was performed in $25 \mu$ reaction mixtures with a final composition of $40 \mathrm{ng}$ of genomic DNA, $0.5 \mu \mathrm{M}$ primer (Sigma), $0.5 \mathrm{mg} / \mathrm{ml}$ of BSA (Sigma), $1.5 \mathrm{mM} \mathrm{MgCl}_{2}, 200 \mu \mathrm{M}$ of each dNTP (Novazym), $1 \times$ PCR buffer $\left(20 \mathrm{mM}\left(\mathrm{NH}_{4}\right) \mathrm{SO}_{4}\right.$, $50 \mathrm{mM}$ Tris- $\mathrm{HCl}, \mathrm{pH} 9.0$ at $25^{\circ} \mathrm{C}$ ), and $1 \mathrm{U}$ of Taq Allegro polymerase (Novazym). Amplifications were carried out in a BIO-GENER Thermocycler with a heated lid under the following block temperature cycle: an initial heat denaturation at $94{ }^{\circ} \mathrm{C}$ for $5 \mathrm{~min}$, five cycles were run at $94{ }^{\circ} \mathrm{C}$ for $1 \mathrm{~min}, 35^{\circ} \mathrm{C}$ for

Table 2 Sequences of the DAMD primers used in the Anthoxanthum aristatum study, with the marker parameters calculated for each primer

\begin{tabular}{llllllrrrr}
\hline Primers & Primer sequences $\left(5^{\prime}-3^{\prime}\right)$ & NTB & NPB & NMB & PPB & PIC & RP & MRP & MI \\
\hline URP13R & TACATCGCAAGTGACACAGG & 22 & 22 & 0 & 100 & 0.31 & 14.54 & 0.66 & 6.82 \\
URP4R & AGGACTCGATAACAGGCTCC & 20 & 19 & 1 & 95.0 & 0.31 & 9.69 & 0.51 & 5.89 \\
D-35 & GATGTGTTCTTGGAGCCTGT & 17 & 17 & 0 & 100 & 0.31 & 10.83 & 0.64 & 5.27 \\
D-38 & AAGAGGCATTCTACCACCAC & 15 & 14 & 1 & 93.3 & 0.24 & 6.71 & 0.48 & 3.36 \\
URP25F & GATGTGTTCTTGGAGCCTGT & 13 & 12 & 1 & 92.3 & 0.27 & 6.40 & 0.53 & 3.24 \\
URP9F & ATGTGTGCGATCAGTTGCTG & 9 & 8 & 1 & 88.9 & 0.22 & 3.51 & 0.44 & 1.76 \\
Total & & 96 & 92 & 4 & & & & \\
Mean & & 16 & 15.3 & & 94.9 & 0.24 & 8.61 & 0.54 & 4.39 \\
\hline
\end{tabular}

$N T B$ number of total bands, $N P B$ number of polymorphic bands, $N M B$ number of monomorphic bands, $P P B$ percentage of polymorphic bands, $P I C$ polymorphic information content, $R P$ resolving power, $M R P$ mean resolving power, $M I$ marker index 
Table 3 Sequences of the SRAP primers used in the Anthoxanthum aristatum study, with the marker parameters calculated for each primer

\begin{tabular}{|c|c|c|c|c|c|c|c|c|c|}
\hline Primers & Primer sequences $\left(5^{\prime}-3^{\prime}\right)$ & NTB & NPB & NMB & PPB & PIC & $\mathrm{RP}$ & MRP & MI \\
\hline Me7 F Em8 R & $\begin{array}{l}\text { TGAGTCCAAACCGGTAA } \\
\text { GACTGCGTACGAATTCTG }\end{array}$ & 17 & 17 & 0 & 100 & 0.35 & 11.23 & 0.66 & 5.95 \\
\hline Me1 F Em11 R & $\begin{array}{l}\text { TGAGTCCAAACCGGATA } \\
\text { CGCACGTCCGTAATTAAC }\end{array}$ & 16 & 16 & 0 & 100 & 0.30 & 7.86 & 0.49 & 4.80 \\
\hline Me4 F Em3 R & $\begin{array}{l}\text { TGAGTCCAAACCGGACC } \\
\text { GACTGCGTACGAATTGAC }\end{array}$ & 10 & 7 & 3 & 70.0 & 0.28 & 4.06 & 0.58 & 1.96 \\
\hline Me7 F Em4 R & $\begin{array}{l}\text { TGAGTCCAAACCGGTAA } \\
\text { GACTGCGTACGAAATTTGA }\end{array}$ & 8 & 6 & 2 & 75.0 & 0.43 & 3.69 & 0.62 & 2.58 \\
\hline Me2 F Em8 R & $\begin{array}{l}\text { TGAGTCCAAACCGGAGC } \\
\text { GACTGCGTACGAATTCTG }\end{array}$ & 6 & 6 & 0 & 100 & 0.39 & 4.57 & 0.71 & 2.34 \\
\hline Me8 F Em14 R & $\begin{array}{l}\text { TGAGTCCAAACCGGTGC } \\
\text { GACTGCGTACGAATTACG }\end{array}$ & 5 & 4 & 1 & 80.0 & 0.42 & 2.69 & 0.67 & 1.68 \\
\hline Me9 F Em1 R & $\begin{array}{l}\text { TGAGTCCAAACCGGATG } \\
\text { GACTGCGTACGAATTAAT }\end{array}$ & 12 & 11 & 1 & 91.7 & 0.37 & 6.43 & 0.58 & 4.07 \\
\hline Me10 F Em2 R & $\begin{array}{l}\text { TGAGTCCAAACCGGGAT } \\
\text { GACTGCGTACGAATTTGC }\end{array}$ & 8 & 7 & 1 & 87.5 & 0.30 & 3.71 & 0.53 & 2.10 \\
\hline Total & & 82 & 74 & 8 & & & & & \\
\hline Mean & & 10.25 & & & 88.0 & 0.36 & 5.53 & 0.61 & 3.19 \\
\hline
\end{tabular}

$N T B$ number of total bands, $N P B$ number of polymorphic bands, $N M B$ number of monomorphic bands, $P P B$ percentage of polymorphic bands, $P I C$ polymorphic information content, $R P$ resolving power, $M R P$ mean resolving power, $M I$ marker index

$1 \mathrm{~min}$ and $72{ }^{\circ} \mathrm{C}$ for $1 \mathrm{~min}$, for denaturation, annealing and extension, respectively. Then, the annealing temperature was raised to $48{ }^{\circ} \mathrm{C}$ for another 35 cycles, followed by final extension step of $10 \mathrm{~min}$ at $72{ }^{\circ} \mathrm{C}$.

The PCR products of both types of markers were separated in $2 \%$ agarose gels containing ethidium bromide at $150 \mathrm{~V}$ for $2 \mathrm{~h}$ at room temperature. The amplified products were visualized using the ethidium bromide staining method under UV light and were documented using the Kodak (1D v. 3.5.4) gel documentation system. Amplified bands were manually scored as present (1) or absent (0); only clear and distinct bands were scored. The Nova 100 bp DNA ladder (Novazym) was used to estimate the size of the bands. PCR was conducted in duplicate to confirm the reproducibility of the banding patterns. One negative control in each amplification was included to exclude contamination.

Statistical analysis was based on 178 loci (96 DAMDs and 82 SRAPs). The obtained binary data matrices were analysed using GenAlEx 6.5 (Peakall and Smouse 2012). The following parameters were used to estimate the genetic diversity of the studied populations: the percentage of polymorphic loci $(P)$, number of different alleles $(A)$, number of effective alleles $\left(A_{e}\right)$, Nei's (1973) gene diversity or the expected heterozygosity $\left(H_{e}\right)$ and Shannon's information index of diversity $\left(I_{s}\right)$. The patterns of the population structure were determined according to the Bayesian clustering method implemented in STRUCTURE v.2.3.4 (Pritchard et al. 2000; Falush et al. 2007). STRUCTURE analysis was performed using a burn-in of 10,000 generations, followed by 100,000 MCMC repetitions and 10 iterations for 1-8 clusters $(K)$ and default settings for other parameters. The optimal number of genetic groups $(K)$ in the dataset was determined based on the $\Delta K$ method (Evanno et al. 2005) using the web-based program Structure Harvester (Earl and von Holdt 2012). The results of STRUCTURE analysis were visualized using the CLUMPAK server (Kopelman et al. 2015).

Analysis of molecular variance (AMOVA) was hierarchically calculated to estimate the allocation of genetic variation for the following configurations: (1) among and within the studied population and (2) at three levels: among two types of habitats (sandy grassland habitats, FR, GA, GF and arable field habitats, $\mathrm{AF}, \mathrm{RF})$, among populations within habitats 
and within populations. The overall and pairwise genetic differentiation between populations were also estimated by AMOVA using $\Phi_{P T}$ statistics (an analogue to $F_{S T}$ ). The statistical significance of the $\Phi_{P T}$ statistic was tested by a permutation test with 1000 permutations. Gene flow as measured by $N_{\mathrm{m}}$ was approximated from the $\Phi_{P T}$ statistic (Cockerham and Weir 1993). Additionally, principal coordinate analysis (PCoA) based on the Nei's (1978) genetic distance matrix was used to illustrate the relationships between individuals and populations. The above analyses were carried out using GenAlEx 6.5. Cluster analysis for all individuals was performed using Mega 6.06 (Tamura et al. 2013) based on the Nei's genetic distances and the Unweighted Pair Group Method with Arithmetic Mean (UPGMA).

The primer banding characteristics, such as the number of total bands (NTB), number of polymorphic bands (NPB), number of monomorphic bands (NMB) and percentage of polymorphic bands (PPB), were calculated from the binary data matrix. To evaluate the usefulness of each primer to distinguish between the studied genotypes, the following measures were computed: marker index (MI) and polymorphic information content (PIC) according to Powell et al. (1996), resolving power (RP) and mean resolving power (MRP) according to Prevost and Wilkinson (1999). The parameters of the genetic diversity of A. aristatum were calculated at the species level.

\section{Results}

Floristic and ecological characteristics of studied habitats

A. aristatum occupies two types of habitats at the eastern limit of its non-native range: field habitats, where regular agrotechnical treatment is conducted (P4, P5, P6, P7), and relatively stable grassland habitats that develop at the edges of coniferous forests and along forest and field roadsides (P1, P2, P3) (Table 4). This species most often occurs in winter crop fields, mainly in rye fields, and recently abandoned fallow lands. These habitats are well lit $(\mathrm{L}=6.9)$, warm $(\mathrm{T}=5.8)$, relatively dry to periodically moist $(\mathrm{F}=3.9)$, moderately to highly acidic $(\mathrm{R}=4.1)$ and poor in nitrogen $(\mathrm{N}=3.9)$. A. aristatum frequently dominates in speciespoor agrocoenoses that occupy this type of habitats, where it covers up to $40 \%$ of the area. More and more often, A. aristatum migrates also into habitats that are less-disturbed than crop fields, i.e., into species-poor sandy grasslands. Some of them are related to $\mathrm{Co}$ rynephorus-Agrostis grasslands, protected by the Habitat Directive-habitat code: 2330 (Interpretation Manual of EU Habitats 2007). Ecological parameters of grassland habitats are similar to agrocoenosis parameters, although the former are even more insolated $(\mathrm{L}=7.8)$, dryer $(\mathrm{F}=3.3)$ and distinctly poorer in nitrogen $(\mathrm{N}=2.7)$. In the conditions of much stronger competition with grassland species, including perennial plants, A. aristatum forms less dense populations that cover up to $20 \%$ of the area.

\section{Polymorphism of DAMD and SRAP markers}

A total of 178 bands were detected in 70 examined individuals of $A$. aristatum, with 96 bands amplified by 6 DAMD primers and 82 by 8 SRAP primers. The parameters that characterized each DAMD and SRAP primer are listed in Tables 2 and 3, respectively. The DAMD primers produced from 9 to 22 bands (average $=16$ ). Most bands were amplified by the primer URP13R, whereas the least efficient primer was URP9F. The resolving power of the analysed DAMD primers ranged from 3.51 to 14.54 . The highest RP value was noted for the primer URP13R, whereas the lowest was recovered for the primer URP9F. The primer URP13R also had the highest values for PIC (0.31) and MI (6.82), while URP9F had the lowest values for both of these parameters. The SRAP primers amplified between 5 and 17 bands, with an average of 10.25 . The highest number of bands was amplified by the primer pair Me7-Em8, and the fewest were amplified by the primer pair Me8-Em14. The resolving power of the analysed SRAP primers ranged from 2.69 (Me8-Em14) to 11.23 (Me7-Em8). The highest PIC value (0.43) was from the primer pair Me7-Em4, whereas the maximum MI value (5.95) was found for the primer pair Me7-Em8. As each individual examined by both types of these markers had its own genotype, seventy genotypes were detected.

Genetic variation within populations

Of the 96 detected DAMD bands, 67 were polymorphic in all of the studied populations. The highest 
Table 4 Floristic and ecological characteristic of habitats occupied by the studied populations of Anthoxanthum aristatum

\begin{tabular}{|c|c|c|c|c|c|c|c|c|c|c|}
\hline \multirow[t]{2}{*}{ Population } & \multicolumn{5}{|c|}{ Floristic parameters } & \multicolumn{5}{|c|}{ Ellenberg's ecological indicator values of } \\
\hline & C.A.a\% & $\mathrm{CB} \%$ & $\mathrm{CC} \%$ & $\mathrm{CD} \%$ & NS & $\mathrm{L}$ & $\mathrm{T}$ & $\mathrm{F}$ & $\mathrm{R}$ & $\mathrm{N}$ \\
\hline \multicolumn{11}{|c|}{ Periodically disturbed habitats (PDH) } \\
\hline $\mathrm{P} 1$ & 37.5 & 0.0 & 80.0 & 10.0 & 25 & 8.0 & 5.9 & 3.3 & 3.1 & 3.3 \\
\hline $\mathrm{P} 2$ & 12.5 & 0.0 & 50.0 & 0.0 & 16 & 7.8 & 5.8 & 3.2 & 4.3 & 2.5 \\
\hline P3 & 3.0 & 0.0 & 70.0 & 10.0 & 21 & 7.6 & 5.8 & 3.3 & 4.2 & 2.4 \\
\hline Mean for PDH & 17.7 & 0.0 & 66.7 & 6.7 & 20.7 & 7.8 & 5.8 & 3.3 & 3.8 & 2.7 \\
\hline \multicolumn{11}{|c|}{ Regularly disturbed habitats (RDH) } \\
\hline P4 & 37.5 & 20.0 & 80.0 & 0.0 & 14 & 6.9 & 5.7 & 4.0 & 4.6 & 4.2 \\
\hline P5 & 37.5 & 60.0 & 50.0 & 0.0 & 11 & 7.1 & 5.7 & 3.6 & 3.9 & 3.3 \\
\hline P6 & 37.5 & 60.0 & 50.0 & 0.0 & 13 & 6.8 & 5.8 & 4.3 & 3.3 & 4.0 \\
\hline $\mathrm{P} 7$ & 37.5 & 50.0 & 80.0 & 0.0 & 11 & 6.9 & 5.9 & 3.7 & 4.7 & 4.0 \\
\hline Mean for RDH & 37.5 & 47.5 & 65.0 & 0.0 & 12.3 & 6.9 & 5.8 & 3.9 & 4.1 & 3.9 \\
\hline Overall mean & 29.0 & 27.1 & 65.7 & 2.9 & 15.9 & 7.3 & 5.8 & 3.6 & 4.0 & 3.4 \\
\hline
\end{tabular}

$C A a \%$ A. aristatum cover, $C B \%$ crop plant cover (Secale cereale), $C C \%$ herb layer cover, $C D \%$ moss layer cover, $N S$ the number of species in phytosociological relevé (the area of $10-25 \mathrm{~m}^{2}$ ), $L$ light indicator values, $T$ temperature indicator values, $F$ moisture indicator values, $R$ soil reaction indicator values, $N$ soil nitrogen content indicator values

number of polymorphic loci was recovered in populations $\mathrm{P} 7-81.25 \%, \mathrm{P} 6-73.96 \%$ and $\mathrm{P} 4-71.88 \%$. The mean percentage of polymorphic loci in populations was $70.09 \%$. The average number of alleles per locus was 1.50 . The mean gene diversity within populations $\left(H_{e}\right)$ for all loci was 0.210 and Shannon's information index $\left(I_{s}\right)$ was 0.33 (Table 5). In SRAP, 4 bands were monomorphic in all of the studied populations of $A$. aristatum. The highest number of polymorphic loci was found in population P6-
$76.83 \%$, whereas the lowest in population P5, this number was $57.32 \%$. The mean percentage of polymorphic loci in the populations was $65.33 \%$. The average number of alleles per locus was 1.50 . The mean gene diversity within populations $\left(H_{e}\right)$ for all loci was 0.217 and Shannon's information index $\left(I_{s}\right)$ was 0.33 . In general, for both types of markers, all of the statistics of genetic variation were higher in populations originating from regularly disturbed habitats $(\mathrm{RDH})$ compared to populations from periodically
Table 5 Comparative list of genetic variability across 7 populations of Anthoxanthum aristatum based on DAMD and SRAP markers

\author{
$A$ number of alleles per \\ locus, $A_{e}$ number of \\ effective alleles per locus, $I_{s}$ \\ Shannon's information \\ index, $H_{e}$ expected \\ heterozygosity, \\ $P$ percentage of \\ polymorphic loci
}

\begin{tabular}{|c|c|c|c|c|c|c|c|c|c|c|}
\hline \multirow[t]{2}{*}{ Population } & \multicolumn{5}{|c|}{ DAMD } & \multicolumn{5}{|c|}{ SRAP } \\
\hline & $A$ & $A_{e}$ & $I_{s}$ & $H_{e}$ & $P$ & $A$ & $A_{e}$ & $I_{s}$ & $H_{e}$ & $P$ \\
\hline \multicolumn{11}{|c|}{ Periodically disturbed habitats (PDH) } \\
\hline $\mathrm{P} 1$ & 1.50 & 1.38 & 0.35 & 0.228 & 69.79 & 1.54 & 1.41 & 0.36 & 0.242 & 68.29 \\
\hline $\mathrm{P} 2$ & 1.39 & 1.25 & 0.27 & 0.166 & 65.63 & 1.43 & 1.31 & 0.28 & 0.183 & 60.98 \\
\hline $\mathrm{P} 3$ & 1.44 & 1.34 & 0.32 & 0.206 & 65.63 & 1.50 & 1.35 & 0.31 & 0.206 & 64.63 \\
\hline Mean for PDH & 1.44 & 1.32 & 0.31 & 0.200 & 67.02 & 1.49 & 1.36 & 0.32 & 0.210 & 64.63 \\
\hline \multicolumn{11}{|c|}{ Regularly disturbed habitats (RDH) } \\
\hline $\mathrm{P} 4$ & 1.54 & 1.35 & 0.34 & 0.217 & 71.88 & 1.38 & 1.36 & 0.31 & 0.209 & 59.76 \\
\hline P5 & 1.39 & 1.30 & 0.29 & 0.186 & 62.50 & 1.35 & 1.30 & 0.27 & 0.176 & 57.32 \\
\hline P6 & 1.54 & 1.37 & 0.35 & 0.229 & 73.96 & 1.70 & 1.47 & 0.40 & 0.269 & 76.83 \\
\hline $\mathrm{P} 7$ & 1.67 & 1.38 & 0.38 & 0.241 & 81.25 & 1.63 & 1.39 & 0.35 & 0.233 & 69.51 \\
\hline Mean for RDH & 1.54 & 1.35 & 0.34 & 0.220 & 72.39 & 1.52 & 1.38 & 0.33 & 0.222 & 65.86 \\
\hline Overall mean & 1.50 & 1.34 & 0.33 & 0.210 & 70.09 & 1.50 & 1.37 & 0.33 & 0.217 & 65.33 \\
\hline
\end{tabular}


disturbed habitats (PDH) (Table 5). However, as the Mann-Whitney U test demonstrated, the differences are not statistically significant.

Genetic structure of populations

The analysis performed with STRUCTURE v2.3.4 based on a Bayesian clustering method suggested the presence of two genetic groups. The optimum number of genetic clusters was estimated using the $\Delta K$ criterion from the Evanno method. The maximal value of $\Delta K$ was 2 in both DAMD and SRAP markers, indicating that the studied individuals can be divided into 2 clusters. Bar plots showed the inclusion of both genetic groups in the studied populations (Fig. 2). Individual populations differed in their share of these genetic groups; populations P1 and P2 from sandy grassland (GA, FR) predominate in the first genetic group (orange cluster), while populations $\mathrm{P} 4$ from recently abandoned field (RF) and P5-P7 from arable fields (AF) formed the second group (blue cluster). Depending on the marker used, population P3 from sandy grassland (GF) fell within the first (in DAMD) or second (in SRAP) genetic group (Fig. 2).

The genetic groups defined using the Bayesian method (Fig. 2) were generally confirmed by PCoA
(Fig. 3), UPGMA clustering (Fig. 4). To determine whether the genetic structure of the studied population was affected by the outlier loci, we repeated the analysis using only putative neutral loci. Removing the outlier loci from the analysis did not significantly affect the genetic structure of the populations (not shown).

Analysis of molecular variance (AMOVA) conducted without the division of the A. aristatum populations into habitat types revealed that most of the genetic variation (72\% and 70\%) was located within populations, regardless of the type of marker used (Table 6). AMOVA with the division of populations into two types of habitats showed that $68 \%$ and $66 \%$ of total genetic variation was still within populations, while the remaining molecular variation was distributed among populations within the habitats (20\% and 21\%) and among habitat types (12\% and $13 \%$ ) in DAMD and SRAP markers, respectively (Table 6). The genetic differentiation ( $\Phi$ statistic) at all hierarchical levels was statistically significant $(P=0.001)$ (Table 6). The gene flow $N_{\mathrm{m}}$ among all of the studied populations estimated from DAMD and SRAP markers was 1.18 and 1.06 migrants per generation, respectively.

The pairwise genetic differentiation $\Phi_{P T}$ between the studied populations ranged from 0.086 to 0.427 in

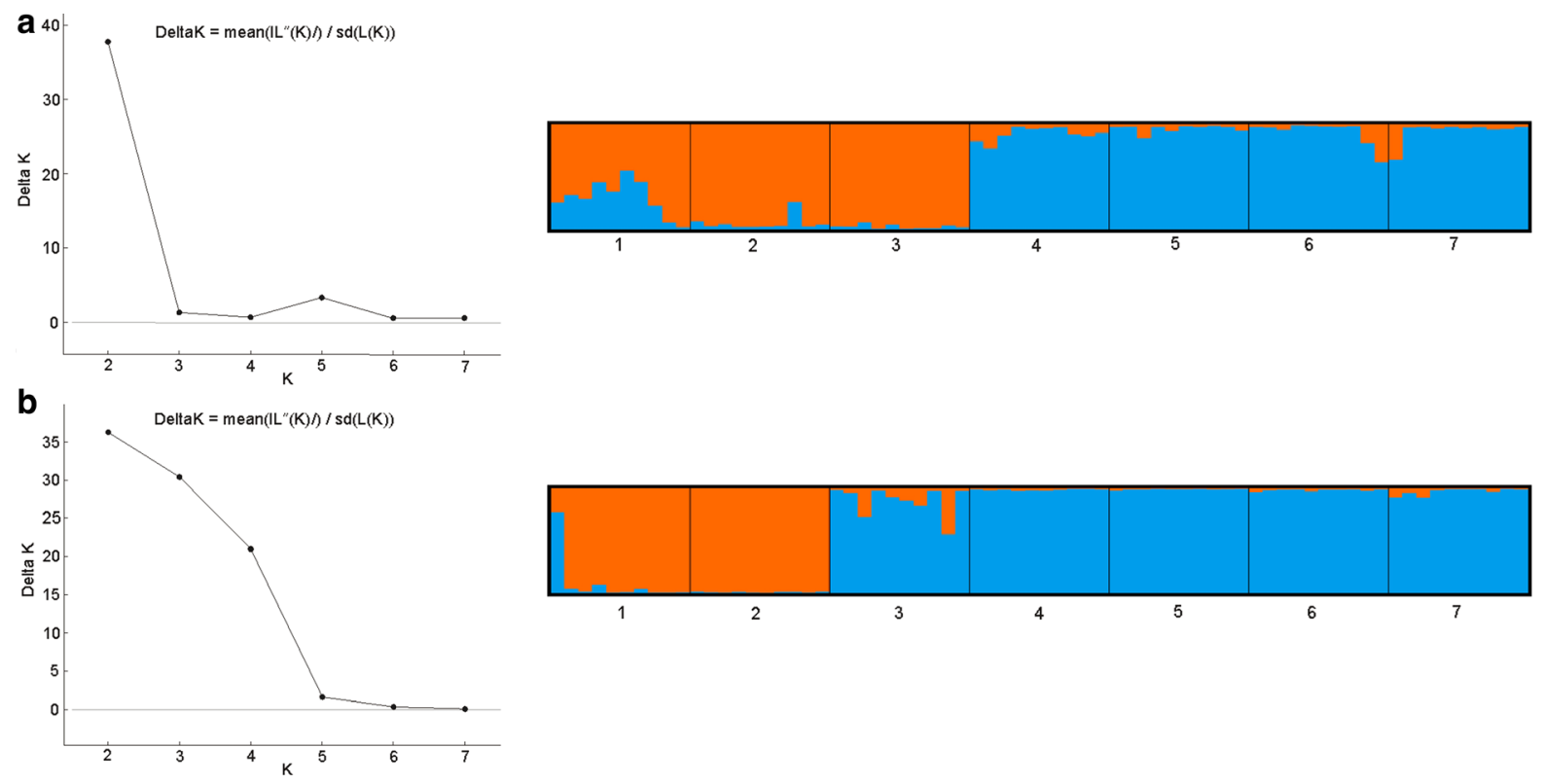

Fig. 2 The results of STRUCTURE analysis of DAMD (a) and SRAP markers (b). Each individual of Anthoxanthum aristatum is represented by a vertical bar showing the degree of admixture.
Populations are separated by black lines. The results for $\Delta K$ are shown on the left side of the bar plot 
Fig. 3 A two-dimensional scatter plot of the first 2 axes of Principal Coordinates Analysis (PCoA) of Anthoxanthum aristatum individuals based on DAMD (a) and SRAP (b) markers

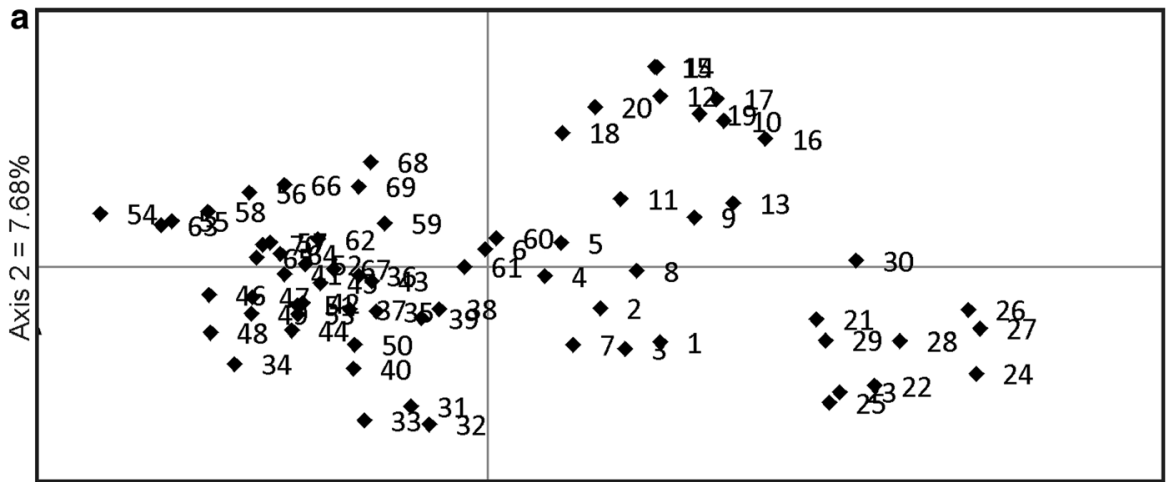

Axis $1=12.47 \%$

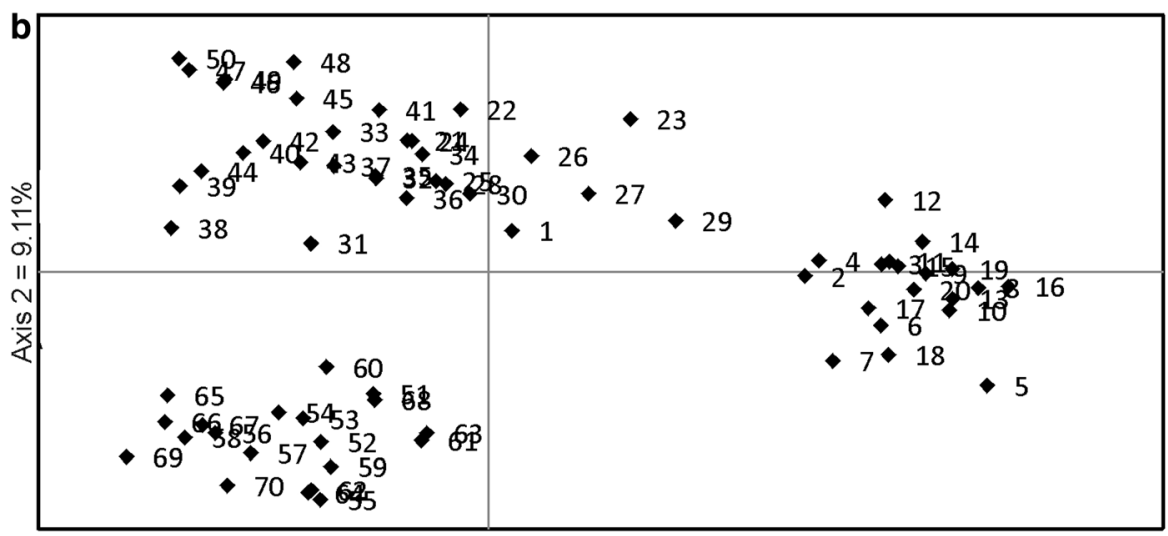

Axis $1=14.14 \%$

Although the indigenous populations of this species were studied with the help of other molecular markers, it is worth noting that their level of polymorphism is even higher. A study of Iberian populations using AFLP markers showed that the proportions of polymorphic loci were $P=87.9 \%$ (Pereira et al. 2007) and $P=87.96 \%$ (Pimentel et al. 2010), whereas the heterozygote frequency was $H_{e}=0.66$ (Pereira et al. 2007). In turn, investigations using microsatellite markers showed that $H_{e}$ ranged from 0.36 to 0.82 , while the polymorphism information content (PIC) ranged from 0.33 to 0.80 (Lema-Suárez et al. 2016). Significant differences in genetic variability among populations located in the centre and at the species natural range limit have already been repeatedly demonstrated (e.g., Eckert et al. 2008; Zhang et al. 2015).

Secondly, our study of A. aristatum invasive populations at the eastern limit of the species nonnative range showed a higher level of intrapopulation than interpopulation variability. AMOVA demonstrated that $72 \%$ and $70 \%$ of genetic variability occurs 
Fig. 4 UPGMA

dendrogram of

Anthoxanthum aristatum

samples based on Nei's

genetic distances for DAMD

(a) and SRAP (b) data. The studied populations are marked by different symbols. Samples: 1-10population P1 (filled circle), 11-20-P2 (open circle), 21-30-P3 (filled square), 31-40_-P4 (open square), 41-50-P5 (filled diamond), 51-60-P6 (open diamond), 61-70-P7 (filled triangle). Blueorange bars to the right of the graphs indicate populations belonging to the groups highlighted in STRUCTURE analysis

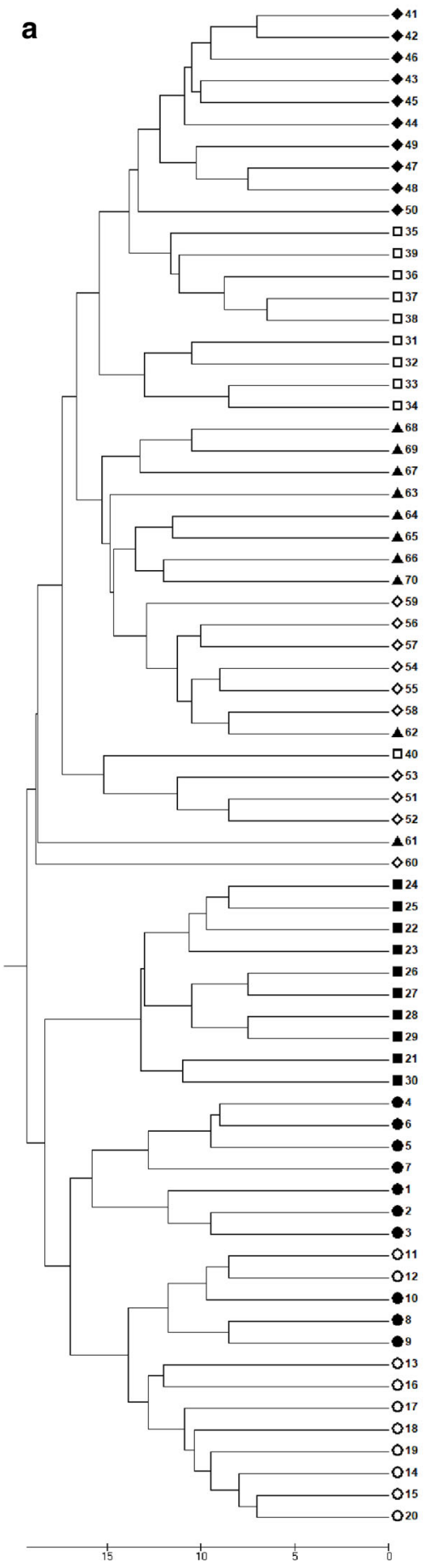

within populations for DAMD and SRAP markers, respectively, while only $28 \%$ and $30 \%$ results from interpopulation differences. Genetic variability of native populations of $A$. aristatum presents a different pattern. Investigations using AFLPs conducted in the

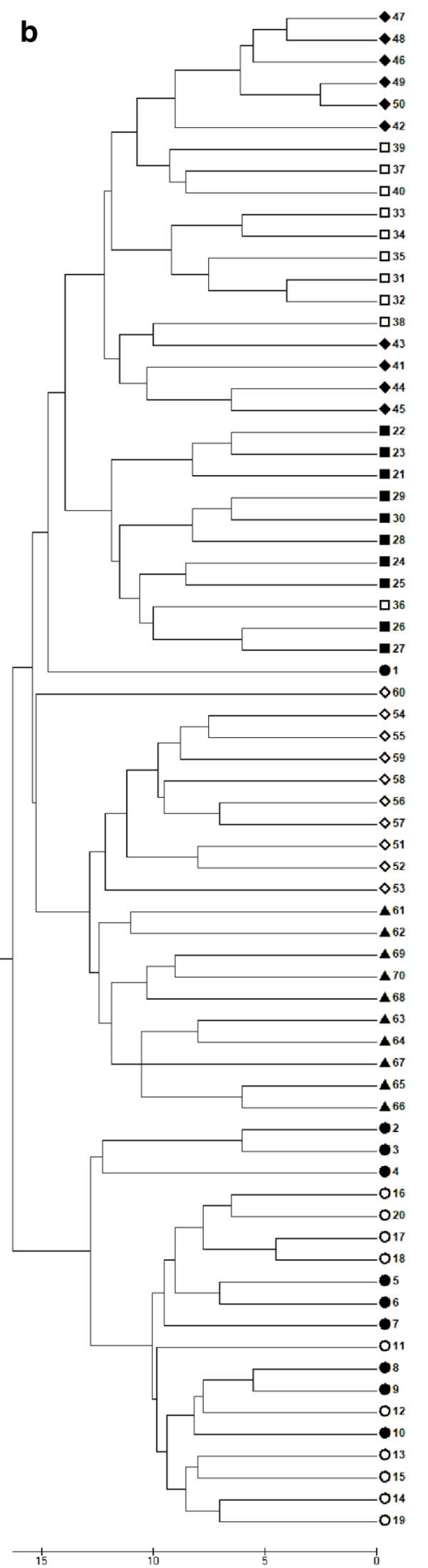

Iberian Peninsula indicated that the interpopulation variability for this species was $77.34 \%$, whereas the intrapopulation variability was $22.66 \%$ (Pereira et al. 2007; Pimentel et al. 2010). 
Table 6 Hierarchical analysis of molecular variance (AMOVA) without (A) and with (B) division of the studied populations of Anthoxanthum aristatum into two types of habitats: periodically disturbed habitats and regularly disturbed habitats, based on DAMD and SRAP markers

\begin{tabular}{|c|c|c|c|c|c|c|}
\hline Source & $d f$ & Sum of squares & Est. Var. & Variance $\%$ & $\Phi$ statistic & $P$ value \\
\hline \multicolumn{7}{|l|}{ A } \\
\hline \multicolumn{7}{|l|}{ DAMD markers } \\
\hline Among populations & 6 & 384.91 & 5.094 & 28 & 0.278 & 0.001 \\
\hline Within populations & 63 & 832.20 & 13.21 & 72 & - & - \\
\hline \multicolumn{7}{|l|}{ SRAP markers } \\
\hline Among populations & 6 & 337.829 & 4.567 & 30 & 0.300 & 0.001 \\
\hline Within populations & 63 & 669.900 & 10.633 & 70 & - & - \\
\hline \multicolumn{7}{|l|}{ B } \\
\hline \multicolumn{7}{|l|}{ DAMD markers } \\
\hline Among habitats & 1 & 128.02 & 2.24 & 12 & 0.116 & 0.001 \\
\hline Among populations within habitats & 6 & 256.89 & 3.82 & 20 & 0.224 & 0.001 \\
\hline Within populations & 63 & 832.20 & 13.21 & 68 & 0.314 & 0.001 \\
\hline \multicolumn{7}{|l|}{ SRAP markers } \\
\hline Among habitats & 1 & 113.86 & 2.02 & 13 & 0.125 & 0.001 \\
\hline Among populations within habitats & 6 & 223.97 & 3.42 & 21 & 0.243 & 0.001 \\
\hline Within populations & 63 & 669.90 & 10.63 & 66 & 0.338 & 0.001 \\
\hline
\end{tabular}

Table 7 Genetic differentiation between the studied populations of Anthoxanthum aristatum $\left(\Phi_{P T}\right.$ ) based on DAMD (below diagonal) and SRAP markers (above diagonal)

\begin{tabular}{llllllll}
\hline & 1 & 2 & 3 & 4 & 5 & 6 & 7 \\
\hline 1 & $* * * *$ & $\mathbf{0 . 0 3 9}$ & 0.255 & 0.317 & 0.372 & 0.307 & 0.308 \\
2 & 0.220 & $* * * *$ & 0.332 & 0.374 & $\mathbf{0 . 4 2 8}$ & 0.373 & 0.398 \\
3 & 0.291 & 0.345 & $* * * *$ & 0.256 & 0.283 & 0.301 & 0.306 \\
4 & 0.185 & 0.324 & 0.346 & $* * * *$ & 0.209 & 0.240 & 0.287 \\
5 & 0.292 & 0.350 & $\mathbf{0 . 4 2 7}$ & 0.148 & $* * * *$ & 0.315 & 0.330 \\
6 & 0.268 & 0.326 & 0.399 & 0.220 & 0.233 & $* * * *$ & 0.116 \\
7 & 0.229 & 0.280 & 0.365 & 0.174 & 0.200 & $\mathbf{0 . 0 8 6}$ & $* * * *$ \\
\hline
\end{tabular}

The lowest and highest values are marked in bold

Thirdly, our study demonstrated that habitat differentiation is reflected in the variation and genetic structure of A. aristatum populations occurring at the non-native range limit. These results refer to the oftendiscussed problem of interactions between an alien species and habitats it colonizes beyond its natural range limit (among others, Dietz and Edwards 2006; Riis et al. 2010; Erfmeier et al. 2011; Pahl et al. 2013; Tunaitiené et al. 2017). Previous studies of plants occurring in habitats differing in use intensity indicate three possible patterns of population genetic diversity: (1) plants in disturbed habitats have higher genotypic and genetic diversity than in stable habitats (Koppitz et al. 2000; Xie et al. 2001; Lambertini et al. 2008); (2) there are no significant differences between the genotypic and genetic diversity of populations occurring in habitats with different disturbance regimes (Solé et al. 2004); and (3) populations in stable habitats are more differentiated than populations in disturbed habitats (Trtikova et al. 2011; Tunaitienè et al. 2017).

In our study AMOVA with the division of populations into two types of habitats (field and non-field) shows that $68 \%$ and $66 \%$ of the total genetic variation remains within populations based on DAMD and SRAP markers, respectively, while the remaining molecular variation was distributed among populations within habitats (20\% and 21\%) and among habitat types (12\% and $13 \%)$. Genetic differentiation $(\Phi$ statistic) at all hierarchical levels was statistically significant $(P=0.001)$.

In the case of $A$. aristatum occurring at its nonnative range limit, our study demonstrated that despite a short period of adaptation, habitat differentiation 
reflects the variation and genetic structure of populations.

It is worth stressing that, irrespective of marker type used, two groups of populations can be distinguished according to Bayesian clustering, PCoA (Fig. 3) and cluster analysis based on Nei's distance. According to the analyses, most groups consisted of populations from similar habitats. The first group comprises populations that inhabit relatively stable habitats (semi-natural sandy grasslands). The second group includes populations connected to field habitats that are regularly disturbed. The affiliation of the population occurring near pine forest is not clear and belongs to either the first or second group depending on the marker used (DAMD or SRAP). This may result from the instability of the habitat and the short-term, transitory character of this type of population. During colonization, A. aristatum is subject to selective pressure, which was supported by a positive alpha factor value (BayeScan analysis), probably favouring genotypes adapted to oligotrophic habitats. This is in accordance with the post-invasion evolution hypothesis (Müller-Schärer and Steinger 2004). A higher level of genetic variability was found in field populations, which may be due to two reasons: (1) a relatively longer time of occurrence in a given habitat compared to sandy grassland populations and necessity of adapting to more dynamic and competitive conditions and (2) more selective ecological barriers separating sandy grasslands from $A$. aristatum migration routes that permit only some ecotypes to enter.

The high genetic diversity populations at the $A$. aristatum non-native range limit in Central Europe and their marked diversity in arable field and sandy grassland habitats suggest that the studied species may systematically cross both geographical and ecological barriers.

\section{Compliance with ethical standards}

Conflict of interest The authors declare that they have no conflict of interest.

Open Access This article is distributed under the terms of the Creative Commons Attribution 4.0 International License (http:// creativecommons.org/licenses/by/4.0/), which permits unrestricted use, distribution, and reproduction in any medium, provided you give appropriate credit to the original author(s) and the source, provide a link to the Creative Commons license, and indicate if changes were made.

\section{References}

Alwala S, Kimbeng CA, Veremis JC, Gravois KA (2008) Linkage mapping and genome analysis in a Saccharum interspecific cross using AFLP, SRAP and TRAP markers. Euphytica 164:37-51. https://doi.org/10.1007/s10681007-9634-9

Bomanowska A, Ferchmin M, Kirpluk I, Otręba A (2014) Invasive plant species in the flora of the Kampinos National Park. In: Otręba A, Michalska-Hejduk D (eds) Invasive plant species in the flora of the Kampinos National Park and its surroundings. Kampinos National Park, Izabelin, pp 25-35 (in Polish)

Brullo S, Cormaci A, Guarino R, Musarella CM (2007) Syntaxonomical survey of Geranio-Cardaminetalia hirsutae: semi-natural therophytic vegetation of the Mediterranean region. Ann Bot 7:183-216

Buczkowska K, Sawicki J, Szczecińska M, Klama H, Milewicz M, Baczkiewicz A (2010) Genetic variation in the liverwort Bazzania trilobata inferred from ISSR markers. J Bryol 32:265-274. https://doi.org/10.1179/ 037366810X12814321877660

Ciosek TM, Skrzyczyńska J (1997) Anthoxanthum aristatum (Poaceae) in the Nizina Południowopodlaska and its neighborhood (Poland). Fragm Florist Geobot 42(2):44-48 (in Polish)

Cockerham CC, Weir BS (1993) Estimation of gene flow from F-statistics. Evolution 47:855-863. https://doi.org/10. 1111/j.1558-5646.1993.tb01239.x

Dietz H, Edwards PJ (2006) Recognition that causal processes change during plant invasion helps explain conflicts in evidence. Ecology 87:1359-1367. https://doi.org/10.1890/ 0012-9658(2006)87\%5b1359:rtcpcd\%5d2.0.co;2

Drapikowska M (2013) Variability of Anthoxanthum species in Poland in relation to geographical-historical and environmental conditions. Biodivers Res Conserv 30:1-93. https:// doi.org/10.2478/biorc-2013-0010

Drapikowska M, Celka Z, Szkudlarz P, Jackowiak B (2012) Variability of the alien species Anthoxanthum aristatum Boiss. (Poaceae) in the Wielkopolska Lowland (Western Poland). Ukr Bot J 69(3):385-392

Drapikowska M, Leśniewska K, Hasterok R, Szkudlarz P, Celka Z, Jackowiak B (2013) Variability of stomata and 45S and $5 \mathrm{~S}$ rDNAs loci characteristics in two species of Anthoxanthum genus: $a$. aristatum and A. odoratum (Poaceae). Acta Biol Hung 64(3):352-363. https://doi.org/10.1556/ abiol.64.2013.3.8

Earl DA, von Holdt BM (2012) Structure Harvester: a website and program for visualizing Structure output and implementing the Evanno method. Conserv Genet Resour 4(2):359-361. https://doi.org/10.1007/s12686-011-9548-7

Eckert CG, Samis KE, Lougheed SC (2008) Genetic variation across species' geographical ranges: the central-marginal hypothesis and beyond. Mol Ecol 17(5):1170-1188. https://doi.org/10.1111/j.1365-294X.2007.03659.x

Ellenberg H, Weber HE, Düll R, Wirth V, Werner W, Paulissen D (1992) Zeigerwerte von Pflanzen in Mitteleuropa; indicator values of plants of Central Europe. Scr Geobot 18:1-258 (in German) 
Erfmeier A, Böhnke M, Bruelheide H (2011) Secondary invasion of Acer negundo: the role of phenotypic responses versus local adaptation. Biol Invasions 13:1599-1614. https://doi.org/10.1007/s10530-010-9917-2

Evanno G, Regnaut S, Goudet J (2005) Detecting the number of clusters of individuals using the software STRUCTURE: a simulation study. Mol Ecol 14(8):2611-2620. https://doi. org/10.1111/j.1365-294X.2005.02553.X

Falush D, Stephens M, Pritchard JK (2007) Inference of population structure using multilocus genotype data: dominant markers and null alleles. Mol Ecol Notes 7:574-578. https://doi.org/10.1111/j.1471-8286.2007.01758.x

Fernández-Moya J, San Miguel-Ayanz A, Cañellas I, GeaIzquierdo G (2010) Variability in Mediterranean annual grassland diversity driven by small-scale changes in fertility and radiation. Plant Ecol 212(5):865-877. https://doi. org/10.1007/s11258-010-9869-8

Fraga i Arguimbau P (2008) Vascular flora associated to Mediterranean temporary ponds on the island of Minorca. Ann Jard Botánico Madrid 65(2):393-414. https://doi.org/ 10.3989/ajbm.2008.v65.i2.302

Heath DD, Lawma GK, Devlin RH (1993) PCR primed with VNTR core sequences yields species specific patterns and hypervariable probes. Nucleic Acids Res 21(24):5782-5785

Hegi G (1909) Illustrated flora of Central Europe. I. Carl Hanser Verlag, München (in German)

Howell C, Sawyer JWD (2006) New Zealand naturalised vascular plant checklist. New Zealand Plant Conservation Network, Wellington

Interpretation Manual of EU Habitats (2007) European Commission Interpretation Manual of European Union Habitats. EUR 27. European Commission, Brussels, Belgium

Jackowiak B, Chmiel J, Latowski K (1990) Segetal communities in winter cereal crops of Wielkopolska. Part 1. Bad Fizjogr Pol Zach Seria B Botanika 40:107-120 (in Polish)

Karaca M, Ince AG (2008) Minisatellites as DNA markers to classify bermudagrasses (Cynodon spp.): confirmation of minisatellite in amplified products. J Genet 87:83-86

Karaca M, Ince AG, Ay ST, Turgut K, Onus AN (2008) PCRRFLP and DAMD-PCR genotyping for Salvia species. J Sci Food Agric 88(14):2508-2516. https://doi.org/10. 1002/jsfa.3372

Kästner A, Jäger EJ, Schubert R (2001) Handbook of segetal plants of Central Europe. Springer, Wien (in German)

Kopelman NM, Mayzel J, Jakobsson M, Rosenberg NA, Mayrose I (2015) Clumpak: a program for identifying clustering modes and packaging population structure inferences across K. Mol Ecol Resour 15(5):1179-1191. https://doi. org/10.1111/1755-0998.12387

Koppitz H, Kühl H, Kohl JG (2000) Differences in morphology and $\mathrm{C} / \mathrm{N}$-balance between clones of Phragmites australis within a plantation at a degraded fen. Folia Geobot 35(4):389-402. https://doi.org/10.1007/BF02803551

Lambertini C, Gustafsson MHG, Frydenberg J, Speranza M, Brix H (2008) Genetic diversity patterns in Phragmites australis at the population, regional and continental scales. Aquat Bot 88:160-170. https://doi.org/10.1016/j.aquabot. 2007.10.002

Lema-Suárez I, Sahuquillo E, Marí-Mena N, Pimentel M (2016) Polymorphic microsatellite markers in Anthoxanthum
(Poaceae) and cross-amplification in the Eurasian complex of the genus. Appl Plant Sci 4(10):1600070. https://doi.org/ 10.3732/apps. 1600070

Li G, Quiros CF (2001) Sequence-related amplified polymorphism (SRAP), a new marker system based on a simple PCR reaction: its application to mapping and gene tagging in Brassica. Theor Appl Genet 103:455-461. https://doi. org/10.1007/s001220100570

Mito T, Uesugi T (2004) Invasive alien species in Japan: the status quo and the new regulation for prevention of their adverse effects. Glob Environ Res 8(2):171-191

Müller-Schärer H, Steinger T (2004) Predicting evolutionary change in invasive, exotic plants and its consequences for plant-herbivore interactions. In: Ehler LE, Sforza R, Mateille T (eds) Genetics, evolution and biological control. CAB International, Wallingford, pp 137-162

Murray MG, Thompson WF (1980) Rapid isolation of high molecular weight plant DNA. Nucleic Acids Res 8(19):4321-4325

Nei M (1973) Analysis of gene diversity in subdivided populations. Proc Natl Acad Sci USA 70:3321-3323

Nei M (1978) Estimation of average heterozygosity and genetic distance from a small number of individuals. Genetics 89(3):83-590

Nie G, Zhang XQ, Huang LK, Xu WZ, Wang JP, Zhang YW, Ma X, Yan YH, Yan HD (2014) Genetic variability and population structure of the potential bioenergy crop Miscanthus sinensis (Poaceae) in Southwest China based on SRAP markers. Molecules 19:12881-12897. https://doi. org/10.3390/molecules190812881

Niemann P, Zwerger P (2006) Population dynamics and competition of annual vernal grass Anthoxanthum puelii Lecoq et Lamotte. Nachrichtenblatt des Deutschen Pflanzenschutzddienstes 58(9):225-227

Oberdorfer E, Schwabe A, Müller T (2001) Phytosociological flora of Germany and adjacent areas. Ulmer, Stuttgart (in German)

Pahl AT, Kollmann J, Mayer A, Haider S (2013) No evidence for local adaptation in an invasive alien plant: field and greenhouse experiments tracing a colonization sequence. Ann Bot 112:1921-1930. https://doi.org/10.1093/aob/ $\operatorname{mct} 246$

Peakall R, Smouse PE (2012) GenAlEx 6.5: genetic analysis in Excel. Population genetic software for teaching and research—an update. Bioinformatics 28:2537-2539. https://doi.org/10.1093/bioinformatics/bts460

Pereira MP, Pérez GE, Balbuena ES (2007) European sweet vernal grasses (Anthoxanthum: Poaceae, Pooideae, Aveneae): a morphometric taxonomical approach. Syst Bot 32(1):43-59. https://doi.org/10.1600/036364407780360 201

Pimentel M, Catalan P, Sahuquillo E (2010) Morphological and molecular taxonomy of the annual diploids Anthoxanthum aristatum and A. ovatum (Poaceae) in the Iberian Peninsula. Evidence of introgression in natural populations. Bot J Linn Soc 164:53-71. https://doi.org/10.1111/j.10958339.2010.01068.x

Pinke G, Pál R, Király G, Szendrödi V, Mesterházy A (2006) The occurrence and habitat conditions of Anthoxanthum puelii Lecoq \& Lamotte and other Atlantic-Mediterranean weed species in Hungary. J Plant Dis Protect 20:587-596 
Powell W, Morgante M, Andre C, Hanafey M, Vogel J, Tingey S, Rafalski A (1996) The comparison of RFLP, RAPD, AFLP, and SSR (microsatellite) markers for germplasm analysis. Mol Breed 2:225-238. https://doi.org/10.1007/ BF00564200

Prevost A, Wilkinson M (1999) A new system of comparing PCR primers applied to ISSR fingerprinting of potato cultivars. Theor Appl Genet 98(1):107-112. https://doi. org/10.1007/s001220051046

Pritchard JK, Stephens M, Donnelly P (2000) Inference of population structure using multilocus genotype data. Genetics 155(2):945-959

Randall RP (2007) The introduced flora of Australia and its weed status. CRC for Australian Weed Management, Glen Osmond

Riis T, Lambertini C, Olesen B, Clayton JS, Brix H, Sorrell BK (2010) Invasion strategies in clonal aquatic plants: are phenotypic differences caused by phenotypic plasticity or local adaptation? Ann Bot 106:813-822. https://doi.org/10. 1093/aob/mcq176

Rivas-Martínez S, de la Fuente V, Sánchez-Mata D (1986) Alisedas mediterráneo-iberoatlánticas en la Península Ibérica. Stud Botánica 5:9-38

Robarts DWH, Wolfe AD (2014) Sequence-related amplified polymorphism (SRAP) markers: a potential resource for studies in plant molecular biology. Appl Plant Sci 2(7):1400017. https://doi.org/10.3732/apps.1400017

Ryves TB, Clement EJ, Foster MC (1996) Alien grasses of the British Isles. Botanical Society of the British Isles City, London

Santa-Bárbara C, Valdés B, Pina FJ (2003) New floristic records for Andevalo area (Huelva Province, SW Spain). IV. Acta Bot Malacit 28:237-246 (in Spanish)

Schneider Ch, Sukopp U, Sukopp H (1994) Biological and ecological foundations of threatened segetal plant protection. Schriftenreihe für Vegetationskunde 26:1-356 (in German)

Sharma SK, Kumaria S, Tandon P, Rao SR (2011) Single primer amplification reaction (SPAR) reveals inter- and intraspecific natural genetic variation in five species of Cymbidium (Orchidaceae). Gene 483:54-62. https://doi.org/10. 1016/j.gene.2011.05.013

Skrajna T, Skrzyczyńska J (2007) Selected biological features and occurrence of Anthoxanthum aristatum Boiss. in the Kałuszyska Upland. Ann Univ Mariae Curie-Skłodowska Lub Pol 62(2):145-155 (in Polish)

Solé M, Durka W, Eber S, Brandl R (2004) Genotypic and genetic diversity of the common weed Cirsium arvense (Asteraceae). Int J Plant Sci 165:437-444. https://doi.org/ $10.1086 / 382801$
Tamura K, Stecher G, Peterson D, Filipski A, Kumar S (2013) Mega 6.06: molecular evolutionary genetics analysis version 6.0. Mol Biol Evol 30:2725-2729. https://doi.org/10. 1093/molbev/mst197

Tokarska-Guzik B (2005) The establishment and spread of alien plant species (kenophytes) in the flora of Poland, vol 2372. Scientific works of the Silesian University in Katowice, Katowice, pp 1-192

Trtikova M, Güsewell S, Baltisberger M, Edwards PJ (2011) Distribution, growth performance and genetic variation of Erigeron annuus in the Swiss Alps. Biol Invasions 13:413-422. https://doi.org/10.1007/s10530-010-9835-3

Tunaitienè V, Patamsytė J, Naugžemys D, Kleizaitė V, Čèsniené T, Rančelis V, Žvingila D (2017) Genetic and allelopathic differences between populations of daisy fleabane Erigeron annuus (L.) Pers. (Asteraceae) from disturbed and stable habitats. Biochem Syst Ecol 70:294-303. https://doi.org/10.1016/j.bse.2016.12.015

Valdés B, Scholz H, von Raab-Straube E, Parolly G (2009) Poaceae (pro parte majore). Euro + Med Plantbase-the information resource for Euro-Mediterranean plant diversity. http://ww2.bgbm.org/EuroPlusMed/. Accessed 15 Nov 2018

Vanderpoorten A, Engels P (2003) Patterns of bryophyte diversity and rarity at a regional scale. Biodivers Conserv 12:545-553. https://doi.org/10.1023/A:1022476902547

Woziwoda B (2010) Variety of flora species of vascular plants in various aged forests on former agricultural soils on the example of grass. Stud Mater Nat For Educ Centre Rogów 12, 2(25):405-416 (in Polish)

Xie ZW, Lu YQ, Ge S, Hong DY, Li FZ (2001) Clonality in wild rice (Oryza rufipogon, Poaceae) and its implications for conservation management. Am J Bot 88:1058-1064

Zając A, Zając M (eds) (2001) Distribution atlas of vascular plants in Poland. Laboratory of Computer Chorology, Institute of Botany, Jagiellonian University, Cracow

Zhang YH, Zhang JW, Li ZM, Sun H (2015) Genetic diversity of the weed species, Stellera chamaejasme, in China inferred from amplified fragment length polymorphism analysis. Weed Biol Manag 15(4):165-174. https://doi.org/10.1111/ wbm.12084

Zitouna N, Gharbi M, Chennaoui H, Touati A, Fadhlaoui I, TrifiFarah N, Marghali S (2015) Characterization of Sulla species via SRAP markers: polymorphism and systematic analyses. Merit Res J Agric Sci Soil Sci 3:089-097

Publisher's Note Springer Nature remains neutral with regard to jurisdictional claims in published maps and institutional affiliations. 